\title{
The value of lung cancer detection by six-monthly chest radiographs
}

\author{
G. Z. B R E T T \\ From the Mass Radiography Service, N.W. Metropolitan Region, 285 Harrow Koad, London W.9
}

\begin{abstract}
Results are reported of a prospective study, carried out by the Mass Radiography Service of the North-West Metropolitan Region for the purpose of evaluating early lung cancer detection by six-monthly chest radiographs. The lung cancer experience of a test group of 29,723 men aged 40 and over who were offered six-monthly chest radiographs over a period of three years is compared with a similarly constituted control group of 25,311 men who were radiographed only at the beginning and the end of the study. In the test group 29,416 men (98.9\%) and in the control group 25,044 men $(99 \%)$ were followed up. The methods employed to achieve this result are analysed. The six-monthly surveys of the test group yielded 65 cases of lung cancer, giving an annual incidence and detection rate of 0.9 per thousand examined. Of these cases $65 \%$ were resected. Of all cases of lung cancer in the test group, irrespective of their source of detection, $43.6 \%$ were operable, compared with $29 \%$ in the control group. The difference $(P=0.03)$ is statistically significant. The annual mortality rate from lung cancer based on 62 deaths in the test group and 59 deaths in the control was 0.7 and 0.8 per thousand respectively. The conelusions are reached that since early detection by six-monthly chest radiographs has not significantly reduced the mortality from lung cancer in a population at risk, a policy of such large-scale surveys of men in the cancer age would not seem justified, but that the increased discovery of resectable lung cancer by this method forms a reasonable basis for encouraging individuals in high-risk groups to make regular use of existing mass radiography facilities.
\end{abstract}

There is an understandable appeal in the hypothesis that early detection of lung cancer by frequent routine chest radiographs of a population at risk might improve the prognosis of the disease. The need to put this hypothesis to a valid test has therefore been felt by many, and in this investigation, conducted by the Mass Radiography Service of the North-West Metropolitan Region, such an attempt has been made. It took the form of a controlled study in which a comparison was made between the lung cancer experience of two random population samples of which one was offered more frequent radiographic examinations than the other. As an investigation on these lines had not been carried out before, its planning and detailed execution contained a large element of improvisation, and in the light of that experience some organizational improvements could be made in a future project of this kind.

Some results based on a $90 \%$ follow-up of those taking part in the study were published in an earlier communication (Brett, 1966). Since then, due to further efforts, a final follow-up of $99 \%$ has been achieved which has now made it possible to conclude the analysis of the project.

\section{PLANNING AND METHOD OF INVESTIGATION}

It was arbitrarily decided to confine the study to men aged 40 and over and to limit its duration to three years. The population under observation would be divided at random into two groups each comprising at least 25,000 persons. The test group would be offered six-monthly chest radiographs during the stipulated period, a total of six in addition to the initial one, whereas the control group would be radiographed only at the beginning and the end of the three-year period. The lung cancer experience to be compared in the two groups would involve detection, resectability, and mortality.

The basic requirement was to secure an adequate number of volunteers for the scheme. Since the Regional Mass Radiography Service has considerable experience in organizing routine surveys of industrial groups, an approach to industry rather than to individuals was thought to have the better prospect of success. For this reason preliminary soundings of 
industrial establishments in the region as to the feasibility of regular six-monthly visits of mobile $x$-ray units were taken during 1956 and 1957. The results were encouraging. It was also realized that to follow up 25,000 persons or more in each group over several years would be a formidable task. In order to minimize these difficulties only firms employing more than 300 men of all ages were approached, since it could reasonably be assumed that the personnel and in many cases medical departments of larger establishments would be better equipped to facilitate the follow-up of their employees. During 1958 the number of men aged 40 and over employed by the firms, whose size made them suitable for the project, was ascertained. The number of potential volunteers was approximately 75,000 men. These industrial establishments, mainly factories, were classified into groups according to the type of work and locality, and the firms within each group were allotted to test and control series by the use of random sampling numbers. The test group consisted of 75 industrial units and the control group was 44 units. $^{2}$

During 1959 all establishments in the test group were visited, and at meetings with representatives of management and workers the reason for the study was explained and discussed. The best way to secure the maximum response from those eligible for the scheme was agreed upon in the light of recommendations from the individual firms. The co-operation of both management and unions was of a high order.

Special record cards were designed to give, in addition to the usual information asked for by Mass Radiography, details of smoking habits (eight questions), health, and the name and address of the examinee's general practitioner. The questions on health referred to chest illness in the past three years and to consultation of general practitioners in the past six months. As all the information had to be subsequently transferred to punch cards used in the Hollerith system, a factory code number and one for each volunteer within that number was allotted to each record card. Addresses were coded according to a five-figure code, occupations into 31 divisions, and social classes into the Registrar General's five divisions. These record cards (in different colours for test and control) were completed by each examinee at the first visit and checked by the clerical staff of the Mass Radiography Service. The record cards for the subsequent visits had only questions relating to possible changes of the information given on the first (master) record card. After the first radiographic examination of the two groups, lists of volunteers for each firm were made. After the second visit to firms in the test group, the problem of defaulters arose. Lists of those radiographed at the second survey were compared with the master list by a factory officer, who indicated the reason for absence. This procedure was adopted for each subsequent visit.

1The difference in the number of firms arose because the random allocation was restricted to ensure that no one series contained substantially more than half the total number of eligible employees.
Before each intermediate survey in the test group leaflets were distributed encouraging those who had started in the scheme to continue with their attendance. Separate leaflets were distributed at the end of the scheme to those in the control group.

The initial surveys of each individual firm in the test or control groups were carried out during 1960 . The subsequent six-monthly surveys in the test group and the final in the control group were completed in $1963 / 64$, when the search for untraced subjects started. These chest radiographs were taken by the three mobile units of the Regional Mass Radiography Service in addition to their normal programme.

\section{MATERIAL AND METHOD OF FOLLOW-UP}

A total of 55,034 men, 29,723 in the test group and 25,311 in the control group, volunteered for the initial survey. During the three years of the scheme 161,225 chest films were taken in the test group and 41,169 in the control group. All examinees in the test group irrespective of whether they had attended the intermediate six-monthly surveys and all examinees in the control group were followed up until the date of their last chest film. Table I shows that the percentage of the population followed up by each of the methods employed was similar in the two groups: about $63 \%$ attended the final survey and a further $36 \%$ were traced by a search of factory records, general practitioners' lists, and by letters to the examinees themselves. It was possible to reduce with the help of the

T A B L E I

METHOD OF FOLLOW-UP

\begin{tabular}{|c|c|c|c|c|}
\hline \multirow{2}{*}{ Method } & \multicolumn{2}{|c|}{ Test Group } & \multicolumn{2}{|c|}{ Control Group } \\
\hline & No. & $\%$ & No. & $\%$ \\
\hline $\begin{array}{l}\text { Final chest radiographs } \\
\text { Information from em- } \\
\text { ployer and general } \\
\text { practitioner .. } \\
\text { Information from }\end{array}$ & $\begin{array}{r}18,789 \\
4,022\end{array}$ & $63 \cdot 2$ & 15,858 & $62 \cdot 7$ \\
\hline $\begin{array}{l}\text { examinee } \\
\text { Ministry of Sociai Security } \\
\text { Untraced } \\
\text { Originally in the scheme } \\
\text { Total followed up }\end{array}$ & $\begin{array}{r}5,462 \\
1,143 \\
307 \\
29,723 \\
29,416\end{array}$ & $\begin{array}{r}18 \cdot 4 \\
3.8 \\
1 \cdot 1 \\
100 \cdot 0 \\
98 \cdot 9\end{array}$ & $\begin{array}{r}5,135 \\
975 \\
267 \\
25,311 \\
25,044\end{array}$ & $\begin{array}{r}20 \cdot 3 \\
3 \cdot 8 \\
1.0 \\
100.0 \\
99 \cdot 0\end{array}$ \\
\hline
\end{tabular}

Ministry of Social Security the percentage of untraced persons from a preliminary $10 \%$ reported previously (Brett, 1966) to about $1 \%$, leaving 29,416 persons in the test group and 25,044 in the control group for further analysis. In all those who were known to have died, the cause of death was established from hospital records and the General Register Office at Somerset House.

COMPARABILITY OF TEST AND CONTROL GROUPS Reference has already been made to the method used in allotting at random component industrial establishments to each group. It can be seen in Table II that 
T A B L E I I

TEST AND CONTROL GROUPS BY AGE AND BASIC SMOKING HABITS

\begin{tabular}{|c|c|c|c|c|c|c|c|c|c|c|c|c|c|c|c|c|}
\hline \multirow{3}{*}{ Age } & \multicolumn{4}{|c|}{ Non-Smokers } & \multicolumn{4}{|c|}{ Ex-Smokers } & \multicolumn{4}{|c|}{ Smokers } & \multirow{2}{*}{\multicolumn{2}{|c|}{$\begin{array}{c}\text { Total in } \\
\text { Each } \\
\text { Age Group }\end{array}$}} & \multirow{2}{*}{\multicolumn{2}{|c|}{$\begin{array}{c}\text { Percentage } \\
\text { of } \\
\text { Total }\end{array}$}} \\
\hline & \multicolumn{2}{|c|}{ Test } & \multicolumn{2}{|c|}{ Control } & \multicolumn{2}{|c|}{ Test } & \multicolumn{2}{|c|}{ Control } & \multicolumn{2}{|c|}{ Test } & \multicolumn{2}{|c|}{ Control } & & & & \\
\hline & $\begin{array}{c}\text { No. Ob- } \\
\text { served }\end{array}$ & $\%$ & $\begin{array}{l}\text { No. Ob- } \\
\text { served }\end{array}$ & $\%$ & $\left|\begin{array}{c}\text { No. Ob- } \\
\text { served }\end{array}\right|$ & $\%$ & $\begin{array}{c}\text { No. Ob- } \\
\text { served }\end{array}$ & $\%$ & $\begin{array}{l}\text { No. Ob- } \\
\text { served }\end{array}$ & $\%$ & $\begin{array}{c}\text { No. Ob- } \\
\text { served }\end{array}$ & $\%$ & Test & $\begin{array}{c}\text { Con- } \\
\text { trol }\end{array}$ & Test & $\begin{array}{l}\text { Con- } \\
\text { trol }\end{array}$ \\
\hline $40-44$ & 958 & $\begin{array}{l}26.9 \\
(13.5)\end{array}$ & 799 & $\begin{array}{c}26.9 \\
(13.0)\end{array}$ & 1,188 & $\begin{array}{c}21 \cdot 4 \\
(16 \cdot 7)\end{array}$ & 1,081 & $\begin{array}{l}21 \cdot 9 \\
(17 \cdot 6)\end{array}$ & 4,952 & $\begin{array}{c}24 \cdot 4 \\
(69 \cdot 8)\end{array}$ & 4,254 & $\begin{array}{c}24 \cdot 8 \\
(69 \cdot 3)\end{array}$ & 7,098 & 6,134 & $24 \cdot 1$ & $24 \cdot 5$ \\
\hline $45-49$ & 1,018 & $\begin{array}{l}28 \cdot 6 \\
(13 \cdot 0)\end{array}$ & 814 & $\begin{array}{c}27 \cdot 4 \\
(12 \cdot 3)\end{array}$ & 1,388 & $\begin{array}{c}25 \cdot 0 \\
(17 \cdot 7)\end{array}$ & 1,214 & $\begin{array}{l}24 \cdot 6 \\
(18 \cdot 3)\end{array}$ & 5,453 & $\begin{array}{r}26.9 \\
(69.4)\end{array}$ & 4,600 & $\begin{array}{l}26 \cdot 8 \\
(69 \cdot 4)\end{array}$ & 7,859 & 6,628 & $26 \cdot 7$ & $26 \cdot 5$ \\
\hline $50-54$ & 709 & $\begin{array}{c}19.9 \\
(11 \cdot 2)\end{array}$ & 634 & $\begin{array}{l}21 \cdot 4 \\
(11 \cdot 4)\end{array}$ & 1,215 & $\begin{array}{c}21.9 \\
(19 \cdot 2)\end{array}$ & 1,090 & $\begin{array}{l}22 \cdot 2 \\
(19 \cdot 6)\end{array}$ & 4,420 & $\begin{array}{c}21 \cdot 8 \\
(69 \cdot 7)\end{array}$ & 3,848 & $\begin{array}{l}22 \cdot 4 \\
(69 \cdot 1)\end{array}$ & 6,344 & 5,572 & $21 \cdot 6$ & 22 \\
\hline $55-59$ & 477 & $\begin{array}{c}13.4 \\
13.7\end{array}$ & 430 & $\begin{array}{l}14 \cdot 5 \\
(10 \cdot 6)\end{array}$ & 1,022 & $\begin{array}{c}18 \cdot 4 \\
(21 \cdot 3)\end{array}$ & 900 & $\begin{array}{c}18 \cdot 3 \\
(22 \cdot 3)\end{array}$ & 3,289 & $\begin{array}{c}16 \cdot 2 \\
(68.7)\end{array}$ & 2,712 & $\begin{array}{c}15.8 \\
(67.1)\end{array}$ & 4,788 & 4,042 & $16 \cdot 3$ & $16 \cdot 1$ \\
\hline $60-64$ & 283 & $\begin{array}{c}7.9 \\
(10.9)\end{array}$ & 208 & $\begin{array}{c}7 \cdot 0 \\
(10 \cdot 1)\end{array}$ & 560 & $\begin{array}{c}10.0 \\
(21 \cdot 6)\end{array}$ & 493 & $\begin{array}{c}10.0 \\
(24.0)\end{array}$ & 1,748 & $\begin{array}{c}8.6 \\
(67.5)\end{array}$ & 1,353 & $\begin{array}{c}8.0 \\
(65.8)\end{array}$ & 2,591 & 2,054 & $8 \cdot 8$ & \\
\hline $65-69$ & 89 & $\begin{array}{c}2 \cdot 5 \\
(14 \cdot 8)\end{array}$ & 71 & $\begin{array}{c}2 \cdot 4 \\
(12 \cdot 8)\end{array}$ & 151 & $\begin{array}{c}2 \cdot 7 \\
(25 \cdot 0)\end{array}$ & 133 & $\begin{array}{c}2 \cdot 7 \\
(24 \cdot 0)\end{array}$ & 363 & $\begin{array}{c}1.8 \\
(60 \cdot 2)\end{array}$ & 350 & $\begin{array}{c}2 \cdot 0 \\
(63 \cdot 2)\end{array}$ & 603 & 554 & $2 \cdot 0$ & $2 \cdot 2$ \\
\hline $70+$ & 28 & $\begin{array}{c}0.8 \\
(21.0)\end{array}$ & 12 & $\begin{array}{c}0.4 \\
(20.0)\end{array}$ & 33 & $\begin{array}{c}0.6 \\
(24.8)\end{array}$ & 14 & $\begin{array}{c}0.3 \\
(23 \cdot 3)\end{array}$ & 72 & $\begin{array}{c}0 \cdot 3 \\
(54 \cdot 1)\end{array}$ & 34 & $\begin{array}{c}0.2 \\
(56.7)\end{array}$ & 133 & 60 & 0.5 & $0 \cdot 3$ \\
\hline Total & 3,562 & $100 \cdot 0$ & 2,968 & $100 \cdot 0$ & 5,557 & $100 \cdot 0$ & 4,925 & $100 \cdot 0$ & 20,297 & $100 \cdot 0$ & 17,151 & $100 \cdot 0$ & 29,416 & $25, \overline{044}$ & $100 \cdot 0$ & $100 \cdot 0$ \\
\hline \multicolumn{3}{|c|}{$\begin{array}{l}\text { Percentage of all men } \\
\text { Test }\end{array}$} & t & $11 \cdot 9$ & & 18.9 & & $19 \cdot 6$ & & $69 \cdot 0$ & & $68 \cdot 5$ & & & 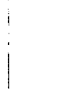 & \\
\hline
\end{tabular}

Figures in parentheses express the percentage of persons in each age group according to their smoking habits. Figures not in parenthese express the percentage of persons in each smoking category according to age group.

the overall age structure and smoking habits as well as the smoking habits within each age group were almost identical for those followed up in the two series. Since this similarity was also apparent in those who were not followed up, the figures in Table II may be representative for industry as a whole.

There were no apparent occupational hazards in any of the firms in either group which should have caused lung cancer. No firm in the control group underwent mass radiography examination during the three-year period of the study. There were too few replies to the questions on health to warrant a special analysis. Thus the comparison between the two random populations did not reveal discrepancies which could constitute bias.

\section{RESULTS}

Table III shows the overall distribution of lung cancer in the test and control groups in relation to the different periods of the investigation at which the disease was discovered. Of the 132 cases in the test group, $96(72 \cdot 7 \%)$ were detected by

\section{T A B L E I I I}

LUNG CANCER EXPERIENCE OF TEST AND CONTROL GROUPS DURING THREE YEARS BY SOURCE OF DETEC-

\begin{tabular}{l|c|c|c|c|c|c}
\hline Group & $\begin{array}{c}\text { Initial } \\
\text { Survey }\end{array}$ & $\begin{array}{c}\text { Six- } \\
\text { monthly } \\
\text { Surveys }\end{array}$ & $\begin{array}{c}\text { Unknown } \\
\text { Source }\end{array}$ & $\begin{array}{c}\text { Final } \\
\text { Survey } \\
\text { after } \\
\text { 3 Years }\end{array}$ & $\begin{array}{c}\text { Total No. of } \\
\text { Cases during } \\
\text { 3-year Period } \\
\text { of Study }\end{array}$ & $\begin{array}{c}\text { Total } \\
\text { No. } \\
\text { of } \\
\text { Cases }\end{array}$ \\
\hline $\begin{array}{l}\text { Test . } \\
\text { Control }\end{array}$ & 31 & 59 & 36 & 6 & 101 & 132 \\
\hline
\end{tabular}

T A B L E I V

FATE OF LUNG CANCER FOUND IN TEST AND CONTROLŌ GROUPS DURING THREE-YEAR PERIOD OF STUDY

\begin{tabular}{|c|c|c|c|c|c|}
\hline & \multirow[b]{2}{*}{$\begin{array}{l}\text { Initial } \\
\text { Survey }\end{array}$} & \multicolumn{2}{|c|}{ Test Group } & \multicolumn{2}{|c|}{ Control Group } \\
\hline & & $\begin{array}{l}\text { Six- } \\
\text { monthly } \\
\text { Surveys }\end{array}$ & $\begin{array}{c}\text { Unknown } \\
\text { Source }\end{array}$ & $\begin{array}{l}\text { Initial } \\
\text { Survey }\end{array}$ & $\begin{array}{c}\text { Unknown } \\
\text { Source }\end{array}$ \\
\hline $\begin{array}{l}\text { Alive .. } \\
\text { Dead .. }\end{array}$ & $\begin{array}{l}11 \\
20\end{array}$ & $\begin{array}{l}33 \\
26\end{array}$ & $\overline{36}$ & $\begin{array}{r}11 \\
9\end{array}$ & $\overline{59}$ \\
\hline Total & 31 & 59 & 36 & 20 & 59 \\
\hline
\end{tabular}

mass radiography and $37(38.5 \%)$ of the 96 caseș in the control group.

From the analysis in Table IV the six cases in? the test group and the 17 in the control group discovered at the final surveys (Table III) were omitted as no case was followed up beyond the three-year period. Of the 59 cases detected in the test group by six-monthly surveys, 33 were alive and 26 were dead at the completion of the scheme It was also found that 36 cases in the test groups and 59 in the control group, discovered elsewheres had died from lung cancer during the intervening period between the first and last radiographs. Of the 36 cases in the test group, 7 had died withind six months of their initial chest film, the remainde? had missed some or all of the six-monthly surveys Of the 59 deaths in the control group, 3 had occurred within six months of the initial examina $\stackrel{?}{\Omega}$ tion.

In all cases discovered by six-monthly survey@ the radiographs preceding the one which led to 
the diagnosis of lung cancer were subsequently reviewed. Radiological abnormalities which, in retrospect, could possibly be related to the disease detected six months later were missed or not acted upon in seven cases; of these, six were still suitable for resection.

DETECTION The rate of detection of lung cancer has been calculated separately for each of the surveys conducted in the test and control groups. Table $\mathrm{V}$ shows that where the interval between the radiographic examinations was approximately three years, as in the initial and final surveys of the control group and the initial survey of the test group, the detection rates were almost identical.

T A B L E V

LUNG CANCER DETECTION AND RESECTABILITY IN TEST AND CONTROL GROUPS

\begin{tabular}{|c|c|c|c|c|}
\hline & \multicolumn{2}{|c|}{ Test Group } & \multicolumn{2}{|c|}{ Control Group } \\
\hline & $\begin{array}{l}\text { Initial } \\
\text { Survey }\end{array}$ & $\begin{array}{c}\text { Final } \\
\text { Survey } \\
\text { after } \\
3 \text { Years }\end{array}$ & $\begin{array}{l}\text { Initial } \\
\text { Survey }\end{array}$ & $\begin{array}{c}\text { Final } \\
\text { Survey } \\
\text { after } \\
3 \text { Years }\end{array}$ \\
\hline $\begin{array}{l}\text { No. radiographed } \\
\text { No. of cases detected } \\
\text { Detection rate per } \\
1,000 \text { examinations } \\
\text { No. of cases resected } \\
\text { Detected growths } \\
\text { resected }(\%) \quad \text {.. }\end{array}$ & $\begin{array}{c}29,723 \\
31 \\
1 \cdot 0 \\
16 \\
52\end{array}$ & $\begin{array}{r}19,695 \\
6 \\
0 \cdot 3 \\
3 \\
50\end{array}$ & $\begin{array}{c}25,311 \\
20 \\
0 \cdot 8 \\
15 \\
75\end{array}$ & $\begin{array}{r}15,858 \\
17 \\
1 \cdot 0 \\
65\end{array}$ \\
\hline
\end{tabular}

On the other hand, where the interval was six months, as in the final survey of the test group, the rate of lung cancer detection was considerably lower. This finding can be attributed to the fact that many cases of lung cancer had already been discovered at the intermediate examinations of this group. This is substantiated by the analysis in Table VI, which also shows that the detection rate for each of the six-monthly surveys was remarkably constant. This made it possible to estimate the mean annual incidence of lung cancer as 0.9 per thousand examined. This was done by the number of cases found at the second to seventh surveys being divided by the mean population under observation each year. This figure is probably lower than the actual incidence, as some subjects will have developed lung cancer between surveys and been missed because of ill health.

The discovery of 65 cases of lung cancer by the six six-monthly surveys and the annual rate of detection resulting from it indicates not only the minimal yield that could be expected each year but also the loss in lung cancer detection that would have been sustained by this population sample had it not been subject to further frequent examinations after the initial survey.

RESECTABILITY To estimate the percentage of resected cases of lung cancer in this series all cases that had occurred in both the test and control groups were taken into account, irrespective of their source of detection. Resectability of lung cancer found by six-monthly routine examinations was compared with that in cases discovered by three-yearly routine surveys and with that in cases detected by methods other than mass radiography. A comparison was also made between the overall resectability in the test group and the overall resectability in the control group. Of the 51 cases discovered by the initial (three-yearly) surveys of both the test and control groups $31(61 \%)$ were resected (Table V) compared with $42(65 \%)$ of the 65 cases detected by six-monthly examinations (Table VI).

It appears that the chance of resection of lung cancer detected by mass radiography surveys is not materially influenced by the frequency with which these examinations are carried out. Since, however, more cases can be discovered by sixmonthly than by conventional three-yearly surveys the actual number of patients who will be given this chance will substantially increase.

There were, however, considerable differences in resectability between lung cancer detected by either six-monthly or three-yearly mass surveys and lung cancer discovered by other means. Thus Table VII shows that in both the test and control groups $65 \%$ of survey-detected lung cancer proved

T A B L E V I

TEST GROUP: LUNG CANCER DETECTION AT SIX-MONTHLY INTERVALS AND RESECTABILITY

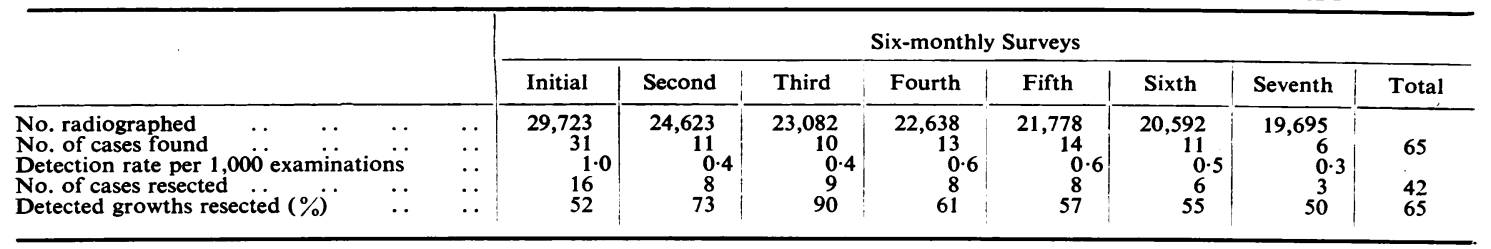


T A B L E V I I

NUMBER AND PERCENTAGE OF RESECTED AND INOPERABLE CASES IN TEST AND CONTROL GROUPS DURINGO THREE YEARS (EXCLUDING INITIAL SURVEYS)

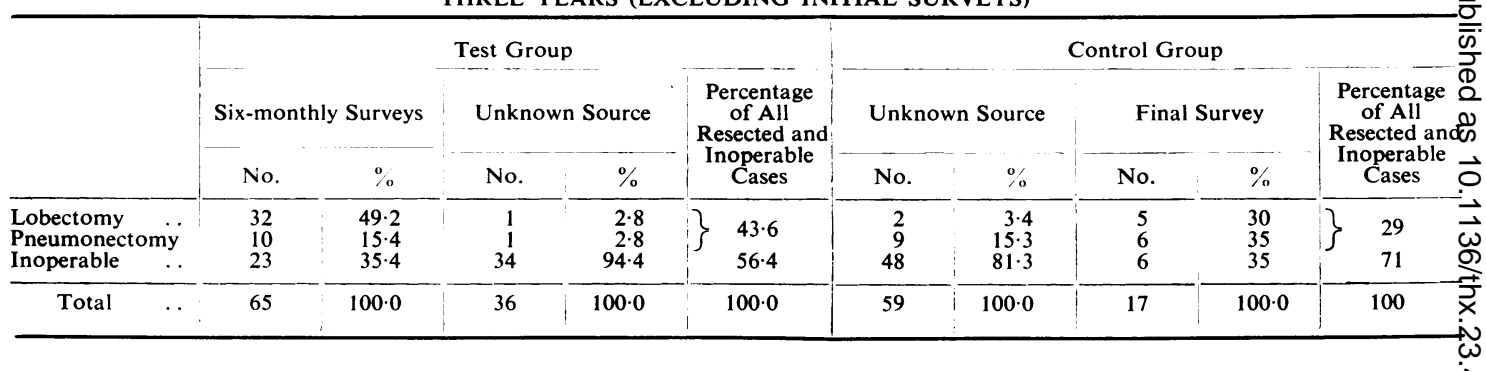

to be operable compared with $5 \cdot 6 \%$ and $18.7 \%$ respectively of cases from an unknown source. In the test group as a whole $43.6 \%$ of cases of lung cancer were resected compared with $29 \%$ in the control group, the difference $(P=0.03)$ being statistically significant. The actual difference is probably higher since cases of lung cancer may not have been recognized in the control series and their deaths could have been attributed to other causes.

The figures in Table VII are comparable to those of an earlier study when it was found that $55 \%$ of cases of lung cancer detected by routine radiography were suitable for resection as against $32 \%$ of cases referred for chest radiography by general practitioners (Brett, 1959).

It is of interest that almost $50 \%$ of the cases found by six-monthly surveys in the test group had resection by lobectomy, compared with $30 \%$ in the final three-yearly survey in the control.

HISTOLOGY Table VIII shows that there were no significant differences in the histological type of lung cancer between the test and control groups or between cases discovered at different intervals of radiographic examinations. The relatively high incidence of adenocarcinoma in this series is in line with the experience of mass radiography in general.
MORTALITY In the calculation of the mortality rates from lung cancer only deaths that had occurred during the three-year period betweeno the first and the last surveys of the two popula? tion samples were taken into account. It was thought that the evaluation of the effect of six monthly surveys on lung cancer mortality in the test group and the comparison with the controb group could be obscured by the inclusion of deaths from the initial surveys, which were conductedo on different lines. The annual mortality rates were therefore, estimated on the basis of 62 deaths fromp lung cancer in the test group and 59 in the controp group. As has been shown in Table IV, the 628 deaths were made up of 26 that resulted from $\vec{b}$ the cases discovered by six-monthly examinations and 36 deaths which occurred in persons in whom? the diagnosis was made elsewhere. Table IX shows that the age-specific annual death rates were similar in the two population samples. The over을 all annual mortality rate was 0.7 per thousano examined in the test group and 0.8 in the controlso A calculation of the rates standardized for age gives the same result. These death rates are somed what lower than the corresponding national figures but not markedly so. The difference in annuab lung cancer mortality between the test group and the control group is not statistically significant bu․ is, nevertheless, consistent with the belief that early

T A B L E V I I I

HISTOLOGICAL TYPE OF LUNG CANCER DETECTED IN TEST AND CONTROL GROUPS

\begin{tabular}{|c|c|c|c|c|c|c|c|c|c|c|c|}
\hline \multirow{3}{*}{\multicolumn{2}{|c|}{ Type }} & \multicolumn{4}{|c|}{ Test Group } & \multicolumn{4}{|c|}{ Control Group } & \multicolumn{2}{|c|}{ Total } \\
\hline & & \multicolumn{2}{|c|}{ First Survey } & \multicolumn{2}{|c|}{ Six-monthly Surveys } & \multicolumn{2}{|c|}{ First Survey } & \multicolumn{2}{|c|}{ Survey after 3 Years } & \multirow{2}{*}{ No. } & \multirow{2}{*}{$\begin{array}{c}\text { Percenta } \\
\text { of } \\
\text { Total }\end{array}$} \\
\hline & & No. & $\%$ & No. & $\%$ & No. & $\%$ & No. & $\%$ & & \\
\hline $\begin{array}{l}\text { Squamous ... } \\
\text { Undifferentiated } \\
\text { Adenocarcinoma }\end{array}$ & \begin{tabular}{l|l} 
& \\
$\cdots$ & \\
$\cdots$ &
\end{tabular} & $\begin{array}{r}12 \\
12 \\
3\end{array}$ & $\begin{array}{l}44 \cdot 4 \\
44 \cdot 4 \\
11 \cdot 2\end{array}$ & $\begin{array}{r}31 \\
24 \\
5\end{array}$ & $\begin{array}{r}51 \cdot 6 \\
40.0 \\
8.4 \\
\end{array}$ & $\begin{array}{r}11 \\
7 \\
1\end{array}$ & $\begin{array}{r}57 \cdot 9 \\
36 \cdot 8 \\
5 \cdot 3\end{array}$ & $\begin{array}{r}8 \\
5 \\
-\end{array}$ & $\begin{array}{c}61 \cdot 5 \\
38 \cdot 5 \\
- \\
\end{array}$ & $\begin{array}{r}62 \\
48 \\
9\end{array}$ & $\begin{array}{r}52 \\
40 \\
8\end{array}$ \\
\hline $\begin{array}{l}\text { Total known } \\
\text { Histology unknown }\end{array}$ & $\cdots$ & $\begin{array}{r}27 \\
4\end{array}$ & $\begin{array}{c}100 \cdot 0 \\
-\end{array}$ & $\begin{array}{r}60 \\
5\end{array}$ & $100 \cdot 0$ & $\begin{array}{r}19 \\
1\end{array}$ & $\begin{array}{c}100 \cdot 0 \\
-\end{array}$ & $\begin{array}{r}13 \\
4\end{array}$ & $100 \cdot 0$ & 119 & 100 \\
\hline Grand total & $\ldots$ & 31 & - & 65 & - & 20 & - & 17 & - & & \\
\hline
\end{tabular}


T A B L E I X

ANNUAL LUNG CANCER MORTALITY IN A 3-YEAR FOLLOW-UP OF TEST AND CONTROL GROUPS

\begin{tabular}{|c|c|c|c|c|c|c|}
\hline \multirow{2}{*}{ Age } & \multicolumn{3}{|c|}{ Test Group } & \multicolumn{3}{|c|}{ Control Group } \\
\hline & $\begin{array}{c}\text { No. } \\
\text { Observed }\end{array}$ & $\begin{array}{l}\text { No. of } \\
\text { Deaths }\end{array}$ & $\begin{array}{c}\text { Rate per } \\
1,000\end{array}$ & $\begin{array}{c}\text { No. } \\
\text { Observed }\end{array}$ & $\begin{array}{l}\text { No. of } \\
\text { Deaths }\end{array}$ & $\begin{array}{c}\text { Rate per } \\
1,000\end{array}$ \\
\hline $\begin{array}{l}40-44 \\
45-49 \\
50-54 \\
55-59 \\
60-64 \\
65-69 \\
70+\end{array}$ & $\begin{array}{r}7,098 \\
7,859 \\
6,344 \\
4,788 \\
2,591 \\
603 \\
133\end{array}$ & $\left.\begin{array}{c}3 \\
4 \\
13 \\
20 \\
17 \\
4 \\
1\end{array}\right\}$ & $\begin{array}{l}0 \cdot 15 \\
0 \cdot 18 \\
0 \cdot 7 \\
1.4 \\
2 \cdot 3 \\
2 \cdot 3\end{array}$ & $\begin{array}{r}6,134 \\
6,628 \\
5,572 \\
4,042 \\
2,054 \\
554 \\
60\end{array}$ & $\left.\begin{array}{r}1 \\
10 \\
14 \\
14 \\
11 \\
8 \\
1\end{array}\right\}$ & $\begin{array}{l}0.06 \\
0.5 \\
0.9 \\
1.2 \\
1.8 \\
4.7\end{array}$ \\
\hline Total & 29,416 & 62 & 0.7 & 25,044 & 59 & $0 \cdot 8$ \\
\hline
\end{tabular}

diagnosis of the disease may have had some small effect on its subsequent course.

\section{DISCUSSION AND CONCLUSIONS}

In an earlier investigation the observation has been made that persons with lung cancer detected by routine three-yearly mass radiography surveys have a better resection rate and a greater chance of survival for five years after resection than patients radiographed on their doctor's advice (Brett, 1959). The present study carries the evaluation of the diagnostic time factor in lung cancer still further by reducing the interval between surveys from three years to six months. This is to our knowledge the first controlled investigation of its kind designed to compare the lung cancer experience of populations rather than individuals. Sixmonthly chest radiographs formed also the basis of the Philadelphia Pulmonary Neoplasm Project begun in 1951 ; its aims and designs were, however, different from those of the present study. A single group of 6,137 men aged 45 and over, not a random sample, was enrolled over a period of four years and followed up for up to 10 years (Boucot, Cooper, and Weiss, 1961).

It has been shown in the earlier part of this report that the organizational difficulties in mounting regular six-monthly surveys for large population groups can be overcome. Whether industry, which co-operated well in a three-year scheme, would be willing to accept long-term six-monthly radiographic examinations of their employees, even if limited to the higher risk age groups of 50 and over, is an open question. It is, however, possible that, given the opportunity, many people in these age groups would take advantage of frequent radiographic facilities on an individual basis and in their own time.

For the assessment of the size of the problem of lung cancer in a working population it was important to establish that the potential annual detection rate of the disease in men over the age of 40 was in the region of one per thousand. This is comparable to the interim results of the Philadelphia Project (Boucot et al., 1961).

The study has shown that due to more frequent examination of the same population sample, 59 cases of lung cancer were discovered which would not have been found at that particular time had only three-yearly surveys been employed. It was of interest to find that the rate of resection in these cases was not significantly higher than in the cases discovered at the initial surveys of both the test and control groups conducted on conventional lines of mass radiography. This finding can perhaps be explained by the following consideration: the longer mass radiography surveys are spaced out, the greater the number of patients with lung cancer that will have been diagnosed by other methods in the intervening period. Thus, the lung cancer that remained to be detected by the actual surveys would have a relatively short period of radiological detectability, probably not substantially different from that in the cancer discover:d by six-monthly surveys. For this reason the extent of the disease might conceivably have been similar and would in turn account for the similarity of the resection figures. That the size of the gap between the possible and the actual detection plays a part in determining the resectability of lung cancer has been demonstrated by the significantly higher rate of resection in cases found by sixmonthly surveys in the test group compared with the cases discovered by other methods in the controls.

In the design and for the purpose of this investigation the comparison of death rates from lung cancer between the test group and the control group was of crucial importance. The lower lung cancer mortality observed in the test group could perhaps be interpreted as an indication that early diagnosis by six-monthly radiographic examinations may have had some effect on the future course of the disease, were it not for the fact that the difference in mortality between the test and control groups was so small. It can be argued that as some cancer deaths must have been missed in the $1 \%$ who remained untraced,-perhaps a higher proportion was missed in the control group than in the test group. However, even if this were the case it is inconceivable that the number of deaths from lung cancer in this fraction of the population would be large enough to affect the overall and differential mortality rates. The view has also been expressed that the very nature of the study has a built-in bias against the test group 
since, by intensive radiology, cases of lung cancer may have been discovered that would otherwise have been missed, so that some deaths which would erroneously have been attributed to some other cause have in the test group, but not in the controls, been correctly attributed to lung cancer (Doll, 1966). If such bias exists it is difficult to see how it could be eliminated. To what extent the mortality figures in the two groups would have been affected had the study been extended beyond three years is a matter for speculation.

The conclusions to be drawn from this study must be based on both its positive and equivocal results, and are therefore subject to qualification. Thus, if the value of six-monthly radiographic examinations is to be measured only by a significant reduction of mortality from lung cancer in a population at risk, then no definite evidence has emerged which would justify a policy of frequent large-scale surveys of this kind. If, on the other hand, the merit of early diagnosis and a better chance of resection for a larger number of cancer patients is linked with even a small reduction in mortality, then there is, without detracting from the importance of prevention by a change of smoking habits, good reason why men in the cancer age should make regular use of the available facilities for routine radiographic examinations.
I am grateful to Dr. J. R. Bignall, Dr. R. Doll, and Professor J. G. Scadding for their interest in the study and their advice in designing it. I am particularly indebted to Dr. R. Doll for his help in assessing the statistical material. My thanks are due to the many industrial medical officers, personnel managers, and shop stewards who helped in the organization of the survey.

I cannot praise too highly the staff of the Regional Mass Radiography Service, who carried the burden of this scheme in addition to their routine work. That this project could have been undertaken and completed is to a large degree due to the hard work and enthusiasm of Miss B. Butcher and Mr. L. Pigden, the 'Organizing Secretaries of the Regional Mass Radiography Service.

This investigation was carried out with the help of a research grant from the N.W. Metropolitan Regional Hospital Board.

\section{REFERENCES}

Boucot, K. R., Cooper, D. A., and Weiss, W. (1961). The Philadelphia Pulmonary Neoplasm Research Project. Ann. intern. Med., 54, 363.

Brett, G. Z (1959). Bronchial carcinoma in men detected by selective and unselective miniature radiography: a review of 228 cases. Tubercle, 40, 192.

(1966). The presymptomatic diagnosis of lung cancer. Proc. roy. Soc. Med., 59, 1208.

Doll, R. (1966). In Symposium on presymptomatic diagnosis. Ibid., $59,1211,1214$. 